\title{
Waste Management And Education Model In The Margosaras Waste Bank; an Islamic Development Perspective
}

\author{
Mufti Afif ${ }^{1}$, Ahmad Lukman Nugraha ${ }^{2}$, Arie Rachmat Soenjoto ${ }^{3}$, Achmad Setiyono, Suyanto . $^{5}$ \\ \{muftiafif@unida.gontor.ac.id ${ }^{1}$, ahmad.lukman.n90@gmail.com², \\ arierachmatsunjoto79@unida.gontor.ac.id $\left.{ }^{3}\right\}$ \\ University of Darussalam Gontor, Ponorogo $0^{1,2,3,4,5}$
}

\begin{abstract}
Waste is a common problem faced by any individual or society, either in the village or in the town. Most waste cases, done by removing the waste to a less strategic place, like in the rivers or illegal lands. This research was conducted to find out the model of waste management and the education in Margosaras waste bank that to improve society's welfare, referring to the Islamic economic development concept from Imam Al-Ghazali. The research uses a qualitative approach with descriptive methods and the data obtained from interviews and observations in the field. The results show, the model of waste management in Margosaras waste bank in Karanggondangan-Klaten has a management method which includes; planning, organizing, staffing, directing, controlling and evaluation, until the members of a waste bank have additional income. The education program has the effect of being aware of the economic value of waste and the craft from the waste. The social welfare of Karanggondangan-Klaten reviewed from the concept of Islamic economic development of Imam Al-Ghazali and achieved from five pods (religion, soul, intellect, descendants and wealth).
\end{abstract}

Keywords: Waste Management, waste bank, education, Welfare.

\section{Introduction}

Islam is a religion teaches people to live healthy through keeping cleanliness, because cleanliness is a part of faith [1]. The waste is a common problem faced by developed and developing countries. In case to solve it, some concepts of waste management are developed. Indonesia as a developing country, the problem of waste becomes a serious matter that needs deeper attention due to the continuous increase of population [2].

An observation done by the department of nature in the Ministry of Environment and Forestry in 2018 mentioned that Indonesia produces 65,8 million tons of waste every year, of which 16 percent is the plastic waste. Java Island became the largest contributor producing 9.710,61 meter cubic in 2016. The total of all wastes come from the waste settlement (housing, apartments, etc.) and nonresidential waste (industry, hospitals, institutions, and etc.). Waste as became the reason of the environment's damage which has negative impacts on society. It impacts on health and the environment life [3]. Meanwhile, the availability of land as a place to process final waste management is more difficult because of the reduced land, notably in the city is decreased. By the increasing level of consumption in the community and other activities, trash or waste continuously increasing. Waste produced by the activities and consumption of 
society which known as domestic or household waste has become an environmental problem where the attention from government and society need to be addressed [4].

Klaten Regency is one of the regions in Indonesia that has participated in handling waste issues involving the local community, which located in Karanggondangan Hamlet, Polan Village, Polanharjo District. Polan Village has four waste banks while in Karanggondangan hamlet itself has a waste bank with an implementation model that can help the society and can be emulated also by other waste banks. This waste bank also acts as a society facilitator in handling waste issues that can help the society from its products [5] and for its success in dealing with the society based waste issues. The program began in 2014 and is called by the waste bank of Margo Saras which is managed by the society itself, from the society and for the society[6].

From the background of the study above, the researchers felt the necessity of this research due to the increasing and uncontrolled waste. The researcher took interest in the waste problem, in which the waste is an unused item, but if it is managed properly it will give economic value. The existence of social motivation in managing waste by managing waste into goods that are more useful and can have an influence on society's welfare. The welfare is not only obtained and reviewed in terms of material aspects but also in spiritual and social concepts.

\section{Theory}

The waste bank is a system of collective dry waste management that boosted the community to participate actively in it. This system will receive, sort, and funnel the waste of economic value in the market, so the public gets the economic benefits from saving waste. The first waste bank in Indonesia is the Gemah Ripah waste bank, established on 2008 in Bantul Regency by the initiative and the wishes of the local community and became the founders of the first waste bank in Indonesia, even in the world [7]. The main purpose of this waste bank is to make the environment cleaner, demonstrate to the community of the importance of hygiene, and to convert waste into more valuable products[8].

According to Mary Parker management is art of problem solving through others hand. Those a manager manages the job and the staff officer implement the job[9]. In other hand Henry Fayol and James A.F. Stoner defined management as a process of planning, organizing, coordinating and supervising toward its resources to reach/achieve the goals effectively and efficiently[10]. T. Hani Handoko said the urgency of management to bring organization goals into reality, the crucial role of keeping the goals and necessities balanced in all aspects and departments in an organization, and the needs to reach the efficiencies and effectiveness of the organization.

Prosperity literally means secure, safe and prosperous. Whereas in the Islamic perspective, welfare is a condition when someone can play a role in advancing this earth in accordance with the nature of humanity as a vicegerent of Allah SWT. While the caliph who served with all construction activities stated that welfare meaning is falah[11] who carries the meaning of sa'adah fi daroeni (hasanah fi Dunya wa hasanah fil akhirah). Imam Al-Ghazali expresses welfare with five matters that need to be implied in Islamic social life more specifically in individual life. Those are, faith (al-din), soul (al-nafs), intellect (al-aql), descendants (al-nasl) and wealth (al-mal). Then, it is divided into three levels of individual and social utility, namely daruriat (needs), hajiat (pleasure), and tahsinat (luxury).

To acquire social welfare on earth, human should be guided by the guidance of God, as Allah says in Surah Al-Araf (7) verse 10 means: 
"We have put on the face of the Earth for thy dear you and us discrimination on the face of the Earth (source) wild. Very few grateful". (Al-Araf: 10)

However Islamic perspective which states that it is contrary to economic development is not limited to satisfaction in material only. Islam covers all aspects of human life, while development covers the construction of a physical (material) and spiritual development (including the mind). Therefore, the Islamic Economic Development demands and bring the humankind toward a balance between happiness in the world and in the hereafter, justice between individual and community rights, safeguarding sustainability in the vicinity of the damage without differentiating between the spiritual factor in the individual and the community, maintaining the sustainability of the natural surroundings of the damage without differentiating spiritual factors or physical factors. Islamic Development is also certainly derived from the Qur'an and hadith.

Environment Education is a crucial element for the viability of human existence on earth. Environment conservation is a real action for natural life and the importance of the next generation. Earth is the only planet that humans can live in, the emergency for keeping it safe from damages is undeniable. People nowadays need to take a role in conserving nature, keeping the world from a waste terrible threat which come worse as the increasing of human population explosion while the earth which never gets wider.

In order to bring the health environment and changing waste into a product that has an economic value into reality, several communities support the programs for home-waste management. Furthermore, the recycling process takes place and giving more benefits as a product for human needs. Some of these products become compost, handicraft, and material producing cattle meals. Thus, waste education and waste management are necessary for the millennial generation as early as possible.

Basically, every human has desires of happiness and the ability to reach falah as his life purpose [12]. Of course, it all existed in the concept of the welfare of mankind itself. Welfare is the main purpose of human life. Understanding of thought, the concept of the welfare of the Imam Ghazali, states that became the base of his entire starting is the concept of maslahah or social welfare or utility or the common good. It is a concept that covers all human activities and makes the relationship between individuals and society. He also explained deeper that the purpose was to improve the welfare of Sharia all mankind, which lies in the protection of the faith (al-din), soul (al-nafs), intellect (al-aql), descendants (al nasl) and wealth (al-mal)[12].

\section{Method}

The location of the research is in Karanggondangan Hamlet, Polan village, Polanharjo district, Klaten regency. Research methodology conducted by the researcher with the approach is descriptive qualitative to make accurate research and get the valid data and thus the object of research performed. And that is in the waste bank of Margo Saras, Karanggondangan Hamlet, Klaten Regency. The data obtained directly from the subject of the research, which are some managers or executive board of the waste bank and from some societies[13] in Karanggondangan hamlet. The data analyzed through observation, interviews, and documentation [13]. 


\section{Result and Discussion}

\subsection{Profile of waste Margo Saras Bank}

Begins with socialization, training of CSR Aqua to the society and the environment clean movement, in 2014 the waste bank is was established Margo Saras. With 30 executive boards and has not had too many customers, the activities undertaken are still at the stage of socialization and the separation of waste to be weighed and managed, which is then sold to the waste collectors. All the society in the Karanggondangan hamlet became the customer of the waste bank in Margo Saras, with 15 active Executive Board. The target of the waste bank is to cover all communities especially in Karanggondangan hamlet, including the early childhood school occupying the kindergarten, Al-Qur'an education, elementary school, and others. With the mission to reduce waste as minimal as possible.

\subsection{The financing of waste Margo Saras bank}

The trash bank of Margo Saras did not take any profits from this activity. The volunteers or the executive board of this waste bank just gives all the benefits and advantages for the society that manage the waste.

\subsection{Model management of waste in Margo Saras Bank}

For financing the operations of waste bank Margo Saras did not take advantage of this activity. The volunteers or the executive board of this waste bank Margo Saras just gives the benefits and advantages for the society that manages the waste.

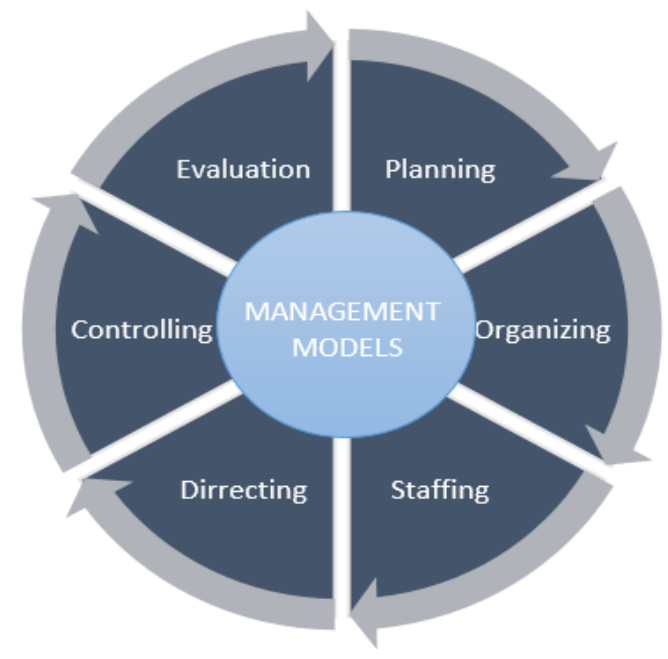

Fig. 1. Stages of Management Model of Waste Bank Margo Saras

Planning: The Households are provided with 4 waste bags; organic waste, plastic, iron, and paper (cardboard). Submission of training and funds sourced from Aqua CSR. Recruitment of 
waste bank members from households and youth organizations. The waste bank will open once in a week, it's on Sunday at 03.00 p.m.

Organizing: The waste has been collected in the houses, and then taken by individuals or by the manager of the waste bank and later be brought to the waste bank. Plastic waste priced for $3000 / \mathrm{kg}$, iron waste for $15.000 / \mathrm{kg}$, and cardboard for $9000 / \mathrm{kg}$. The results of the waste are saved in the waste bank and exchanged with the balance which will be entered into a savings book that may be taken at other times or exchanged for rice at the time. The results of the waste become a compost, arranged into crafts, and sold to the waste collectors.

Staffing: The waste bank structure consists of the chairman, secretary, treasurer, compost team, creative team, and assisted with a youth organization in 2 other hamlets. The compost team is tasked with recycling waste that cannot be reused into compost such as; vegetables, kitchen ingredients, leftovers, and leaves. The creative team is tasked with making a sample form of goods that will be created in collaboration with housewives using items that can be reused, such as; plastic wrap, woods scraps, iron, and glassware.

Directing: Every team directs its members to work in the environment. The composting team collects the waste that cannot be reused and processes it into compost. The creative team directs households to contribute to the making of valuable goods for sale items; bags, wallets, pillows, etc. Youth organization people direct the society to collect household waste and apply it which the waste cans in front of the house. Besides society, kindergarten children are also directed to collect waste.

Controlling and Evaluation: The supervision of Margo Saras waste bank which the education to the society cross-age in collaboration with the head of the neighborhood association and community association, working with the youth organization for collecting of waste in every week, Margo Saras waste bank controls the cleanliness of the environment. Waste bank fosters social togetherness and awareness of caring the waste. In every Sunday morning, the Qur'an recitation is held in evaluation and education in the local clean environment, which the creative training is held for the reciters. General evaluations carried out to adjust the recitation schedule, this weekly evaluation held every night of Sunday to evaluate the organization of Margo Saras waste bank.

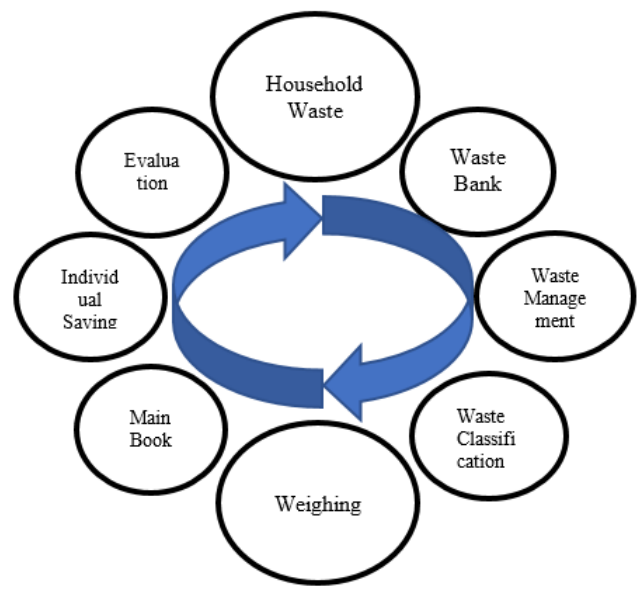

Fig. 2. Stages of Waste Bank Margo Saras Implementation 
This implementation phase is one of the most important stages in the process of running the model of the waste bank to the welfare of society. The formation of Margo Saras waste bank was initiated by society itself. As for the implementation of the waste bank, is done by the administrators and the society; Implementation of Work Program, Implementation of Weighing, and Stages Management of Margo Saras Waste Bank

\subsection{Islamic Economic Development Review on the Waste Bank}

As for ensuring the protection of the public interest warrant these five matters, a welfare concept presented by Imam Al-Ghazali as follows;

Table 1. Relationship Implementation of the waste bank with the welfare Imam Ghazali

\begin{tabular}{cl}
$\begin{array}{c}\text { Indicators of } \\
\text { Welfare }\end{array}$ & \multicolumn{1}{c}{ Implementation of Waste Bank Model at Margo Saras } \\
\hline Hifdzu Dinn & $\begin{array}{l}\text { Worship according to the teachings of Islam. } \\
\text { Hold a recitation of reading the Qur'an every Sunday and on certain days. } \\
\text { Hold the waste charity program. }\end{array}$ \\
Hifdzu Aql & $\begin{array}{l}\text { Organizing the socialization and briefing with the society will sustain the } \\
\text { importance of keeping the environment with the program and the implementation } \\
\text { of the waste bank model. } \\
\text { Invite children to attend an early childhood program on waste charity. }\end{array}$ \\
Hifdzu Aql & $\begin{array}{l}\text { Hold a volunteering program and mutual work. } \\
\text { Conduct craft training or creations of the waste. }\end{array}$ \\
Hifdzu Nasl & $\begin{array}{l}\text { Invite children to participate and to maintain environmental sustainability. } \\
\text { Open the waste bank seven days a week. }\end{array}$ \\
& $\begin{array}{l}\text { Hold a sorting and weighing the waste to be exchanged with goods are valuable. } \\
\text { Make creations from waste to produce something valuable. }\end{array}$ \\
\hline
\end{tabular}

\subsection{The waste education models}

Environmental education is an important element for the survival of human life on earth. Preserving the environment means caring for natural life and future generations [14]. Only on the earth of living, there to save guarding and saving the earth from the damage.
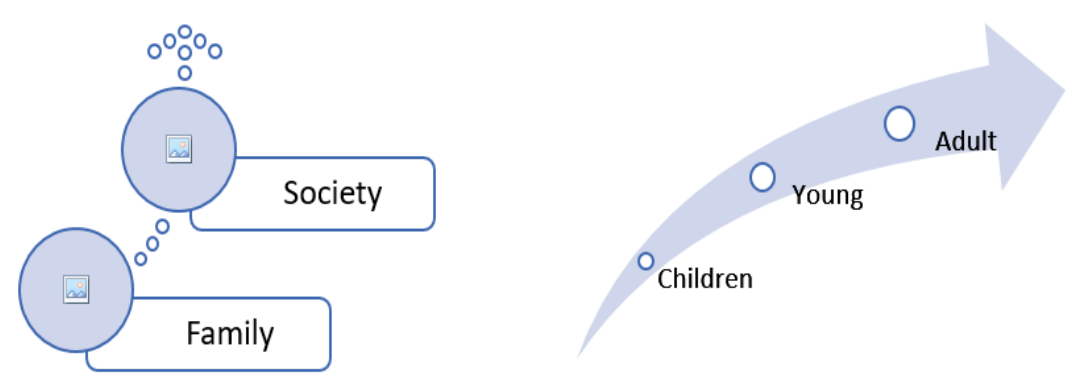

Fig. 2. The Cycle of Education Waste Model 
Today's people must take a role in maintaining environmental health, guarding the earth against the threat of waste that is uncontrollably increased with the explosive growth of the human population[15] while the land area on earth remains the same. To create healthy and valuable environment products, several communities support the household waste management program. Household waste is recycled to become a beneficial product for human needs. There are recycled into manure, handicraft products, and animal meal ingredients. Therefore waste management education is very important especially for the younger generation and needs to be planted as early as possible.

Waste bank education

Education on the waste bank management in the village has been implemented early, namely the generation of children, adolescents and adults. As for the educational model begins from the family sphere to the community.

Child

From an early age, children in the village Puloharjo have been trained about environmental hygiene. In the kindergarten and primary school, children are taught about the creativity of managing waste into useful craft items. Every week children learn out of the classroom, the purpose of this natural class is to bring children closer to the natural environment and foster environmental awareness.

Teenager

After growing concern for the environment. Teenagers are involved in youth organizations. In Pulonharjo village youth organizations involved in the waste management structure Margosaras waste bank. Teenagers in youth clubs are tasked with reminding residents to collect household waste before Sunday. In Sunday they flocked to push the cart around the household collecting the garbage that each household had placed. At 5 p.m they took the waste to the Margosaras waste bank to be weighed and got cash savings from the youth organization.

Adult

The waste bank provides counseling skills for residents on Sunday, the people of Pulonharjo village carry out regular recitations managed by the Margosaras garbage bank. After the recitation, it was continued with garbage counseling and how to increase the value of waste. Waste transformed from worthless items into a craft that has a sale value; bags, carpets, wallets etc. This garbage bank provides a high price to process waste collectors such as $500-1000 / \mathrm{kg}$ of plastic waste, but while they cutting-shape plastic priced $9000 / \mathrm{kg}$ for a pillow filling material.

Family

The initial waste of bank education was implemented in the family environment. Each family is given four waste bags; plastic waste, organic, iron, and glass waste. The household is responsible for the cleanliness of the surrounding environment. Society, with routine recitation. This agenda has an impact on social behavior that cares about waste and forms a harmonious society and mutual cooperation. 


\section{Conclusion}

Integrating Islamic Economic Development is a social process in the sake of economic, education, health, social, or even culture welfares. And to be underlined, all of these processes are on the track of Islamic teachings. The bond built between Margo Saras waste bank and the resident in this society is an effort to increase life-welfare. Welfare measurement could be seen from how each individual lives. Since no numerical measurement due to the life-welfare. (1) The implementation of Margo Saras waste bank done by stages; planning, associating (volunteering, weighing and managing), and evaluating. (1) Welfare levels of this society with the implementation of this waste bank reviewed by Islamic Economic Development are as follow; (a) Since this concept applied by using Imam Al-Ghazali's welfare concept, the implementation of the waste bank could be seen from Imam Al-Ghazali's concepts, (b) This welfare concept is including five main matters on the guarding the faith (al-din), soul (al-nafs), intellect (al-aql), descendants (al nasl) and wealth (al-mal).

\section{References}

[1] R. Wijaya, "Implementasi Konsep Kebersihan Sebagian Dari Iman Di Iain Raden Fatah Palembang," Tadrib J. Pendidik. Agama Islam, vol. 1, no. 1, pp. 171-186, 2017.

[2] E. Damanhuri, "Teknologi Dan Pengelolaan Sampah Kota Di Indonesia," in ITB Bandung, 2006, no. April, pp. 1-11.

[3] U. Mahmudah, W. H. Cahyati, and A. S. Wahyuningsih, "Keberadaan Tps Legal Dan Tps Ilegal Di Kecamatan Godean Kabupaten Sleman," J. Kesehat. Masy., vol. 8, no. 2, pp. 113-120, 2013.

[4] Y. Puspitawati and M. Rahdriawan, "Kajian Pengelolaan Sampah Berbasis Masyarakat dgn Konsep 3R di Kelurahan Larangan Kota Cirebon,” J. Pembang. Wil. dan Kota, vol. 8, no. 4, pp. 349-359, 2012.

[5] D. Wulandari, S. Hadi Utomo, and B. S. Narmaditya, "Waste bank: waste management model in improving local economy," Int. J. Energy Econ. Policy, vol. 7, no. 3, pp. 36-41, 2017.

[6] M. Afandi et al., "Pendekatan Integratif Dalam Pelestarian Sub Das Pusur Kabupaten Klaten," in Restorasi Sungai; Tantangan dan Solusi Pembangunnan Berkelanjutan, 2018, no. 7, pp. 349361.

[7] Munawir, "Bank Sampah: Upaya Pemberdayaan Masyarakat dan Penanganan Lingkungan," Bisnis dan Manaj., vol. 01, no. 01, pp. 31-37, 2015.

[8] A. D. Prastiyantoro, "Partisipasi masyarakat dalam pengelolaan bank sampah gemah ripah di dusun badegan desa bantul," J. Pendidik. Luar Sekol., vol. 6, no. 8, pp. 777-784, 2017.

[9] T. H. Handoko, Manajemen Edisi 2, 2nd ed. Yogyakarta: BPFE-Yogyakarta, 1984.

[10] K. Darr, "Introduction to management and leadership concepts, principles, and practices," Essentials Manag. Leadersh. public Heal., p. 180, 2011.

[11] N. Kholis, "Kesejahteraan Sosial Di Indonesia Perspektif Ekonomi Islam," Akademika, vol. 20, no. 2, pp. 244-260, 2015.

[12] S. M. Ghazanfar and A. A. Islahi, "Economic Thought of an Arab Scholastic: Abu Hamid AlGhazali (A.H. 450-505/A.D. 1058-1111),” Hist. Polit. Econ., vol. 22, no. 2, pp. 381-403, 2009.

[13] Sugiyono, Metode Penelitian Kualitatif, 3rd ed. Bandung: Alfabeta, 2017.

[14] H. P. Putra, A. R. Taufiq, and A. Juliani, "Studi Hubungan antara Tingkat Pendidikan dan Pendapatan Keluarga terhadap Sikap dalam Pengelolaan Sampah Rumah Tangga," J. Sains dan Teknol. Lingkung., vol. 5, no. 2, pp. 91-101, 2013.

[15] M. Bodog, "The concept of waste Management," Univ. Oradea, Fac. Enviromental Prot., vol. XIV, no. April, pp. 669-673, 2009. 